\title{
Spektrum Klinis Demam Berdarah Dengue pada Anak
}

\author{
Edi Hartoyo
}

Bagian Ilmu Kesehatan Anak Fakultas Kedokteran Universitas Lambung Mangkurat/RSUD. Ulin Banjarmasin

Latar belakang. Demam berdarah dengue (DBD) merupakan penyakit endemis di beberapa daerah di dunia. Setiap tahunnya WHO melaporkan 50-100 juta terinfeksi virus dengue dengan 250-500 ribu menderita DBD dan 24.000 di antaranya meninggal dunia. Di Indonesia, 12 dari 30 propinsi di antaranya merupakan daerah endemis DBD dengan case fatality rate $1,12 \%$.

Tujuan. Untuk mengetahui gambaran klinis, laboratorium, serta mengevaluasi terapi yang telah diberikan pada penyakit demam dengue/DBD.

Metode. Penelitian ini merupakan penelitian deskriptif analitik, subjek adalah pasien yang di rawat di Bagian Anak RSUD Ulin Banjarmasin periode Januari 2007 sampai dengan Febuari 2008 dengan diagnosis demam dengue/DBD/sindrom syok dengue (SSD) berdasarkan kriteria WHO tahun 1997 dan dilakukan uji serologi (rapid test Panbio Australia). Analisis data dengan program SPSS 13 for window.

Hasil. Dari 123 subjek gejala klinis yang mencolok adalah demam 93,5\%, muntah 65,1\%, nyeri perut $50,4 \%$, ruam konvalesen $47,1 \%$, pusing $19 \%$, batuk $17,9 \%$, pilek $9,8 \%$, perdarahan gusi $6,5 \%$, epitaksis $4,1 \%$, dan melena 3,3\%. Pada pemeriksaan fisik uji forniket positif $62,6 \%$, hepatomegali $38,2 \%$, efusi pleura $37,4 \%$, dan asites $27,6 \%$. Hasil laboratorium menunjukkan rerata angka leukosit lebih rendah pada SSD dibandingkan dengan DD dan DBD, dan secara statistik berbeda bermakna $(p=0,007)$, nilai rerata hematokrit lebih tinggi pada SSD dibandingkan DBD dan DD, secara statistik berbeda bermakna $(p=0,049)$, rerata nilai trombosit SSD lebih rendah. Kadar SGOT 76,7\% dan SGPT $86 \%$ meningkat pada SSD. Penggunaan cairan kristaloid pada demam dengue $81,1 \%$, DBD $86,4 \%$ dan SSD $86,1 \%$ dari semua kasus, sedangkan penggunaan cairan koloid pada SSD 56,1\%.

Kesimpulan. Gejala klinis yang mencolok 1 demam, mual, muntah, nyeri perut, epitaksis, dan melena. Pemeriksan fisik, yang mencolok uji forniket positif, ruam konvalesen, hepatomegali. Leukopenia, trombositopenia serta peningkatan SGOT/SGPT lebih banyak dijumpai pada DBD dan SSD dari pada DD. (Sari Pediatri 2008;10(3):145-150).

Kata kunci: SSD, nilai leukosit, hematokrit dan trombosit.

\author{
Alamat Korespondensi: \\ Dr. Edi Hartoyo., SpA. Staf SMF Kesehatan Anak FK. UNLAM-RSUD \\ Ulin. Jl Jendral A.Yani 43, Banjarmasin Kalimantan Selatan.
}

Sari Pediatri, Vol. 10, No. 3, Oktober 2008 
I nfeksi virus dengue endemis di beberapa daerah tropis dan subtropis, dan lebih dari 100 negara di Afrika, Amerika, Mediterania, Asia Selatan, dan Fasifik Barat. Sekitar 2,5 juta penduduk di daerah tersebut pernah terinfeksi virus dengue. Menurut WHO terdapat kira-kira 50 - 100 juta kasus infeksi virus dengue setiap tahunnya, dengan 250.000-500.000 demam berdarah dengue (DBD) dan 24.000 di antaranya meninggal dunia. ${ }^{1} \mathrm{Di}$ Indonesia DBD merupakan masalah kesehatan, karena hampir seluruh wilayah Indonesia mempunyai risiko untuk terjangkit infeksi dengue. Dua belas di antara 30 provinsi di Indonesia merupakan daerah endemis DBD, dengan case fatality rate $1,2 \% .{ }^{2}$ Virus penyebab dan nyamuk sebagai vektor pembawa tersebar luas di perumahan penduduk maupun fasilitas umum. Penyakit DBD disebabkan oleh virus famili Flaviviridae, genus Flavivirus yang mempunyai 4 serotipe yaitu den 1 , den 2 , den 3 , dan den 4 . Virus ini ditularkan ke manusia melalui gigitan nyamuk Aedes aegypti dan Aedes albopictus yang tersebar luas di seluruh Indonesia. Perjalanan penyakit dengue sulit diramalkan, manifestasi klinis bervariasi mulai dari asimtomatik, simtomatik (demam dengue, DBD), DBD dapat tanpa syok atau disertai syok (SSD). Pasien yang pada waktu masuk rumah sakit dalam keadaan baik sewaktu-waktu dapat jatuh ke dalam keadaan syok (SSD), oleh karena itu kecepatan menentukan diagnosis, monitor, dan pengawasan yang ketat menjadi kunci keberhasilan penanganan DBD.

Angka kesakitan DBD cenderung meningkat di Indonesia mulai 0,05 per 100.000 penduduk pada tahun 1968 menjadi 35,19 per 100.000 penduduk pada tahun 1998. Program pencegahan dan pemberantasan DBD dilaksanakan secara integral mencakup survailans laboratory based study, penyuluhan, pendidikan pengelolaan pasien bagi dokter, paramedis, dan pemberantasan sarang nyamuk dengan peran serta masyarakat. ${ }^{2,3}$

\section{Metode}

Penelitian diskriptif analitik dengan subjek pasien yang dirawat di Bagian Anak RSUD Ulin Banjarmasin antara Januari 2007 sampai dengan Febuari 2008 dengan diagnosis (DBD/DD) berdasarkan kriteria WHO tahun 1997 dan dikonformasi dengan serologi IgG/IgM (dengue strip rapid tes Panbio Australia).
Pemeriksaan serologi dilakukan pada hari ke 4 sampai hari ke 6 (fase akut). Apabila hasil pemeriksaan pertama negatif, diulang pada saat berobat untuk kontrol (fase konvalesen). Infeksi primer apabila pada fase akut IgM positif dan infeksi sekunder bila pada fase akut IgM dan IgG positif atau hanya IgG positif. Penentuan status gizi berdasarkan kriteria CDC 2000. Sampel dianalisis dengan SPSS 13. Untuk nilai leukosit, hematokrit, dan trombosit dilakukan analisis $t$ test.

\section{Hasil}

Dalam kurun waktu Januari 2007 sampai dengan Febuari 2008 terdapat 123 anak yang dirawat dengan diagnosis DD/DBD/SSD berdasarkan kriteria WHO tahun 1997 dan dilakukan uji serologi anti dengue.

Angka kejadian DBD/DD terbanyak pada umur 5-10 tahun, 52 anak (42,4\%). Berdasarkan distribusi jenis kelamin, laki-laki lebih banyak 66(54,6\%)

Tabel 1. Karateristik dasar pasien demam berdarah dengue/ demam dengue.

\begin{tabular}{llc}
\hline No & \multicolumn{1}{c}{ Variabel } & Jumlah (\%) \\
\hline 1. & Umur (tahun) & $44(35,7)$ \\
& $<5$ & $52(42,4)$ \\
& $5-10$ & $27(21,9)$ \\
& $>10-14$ & \\
2. & Jenis kelamin & $66(54,6)$ \\
& Laki-laki & $57(45,4)$ \\
& Perempuan & \\
3. & Status gizi & $82(66,6)$ \\
& Baik & $38(30,8)$ \\
& Kurang & $3(2,6)$ \\
& Buruk & \\
4. Diagnosis & $21(17,2)$ \\
& DD & $59(47,9)$ \\
& DBD (derajat 1 dan 2) & $43(34,9)$ \\
& SSD ( DBD derajat 3 dan 4) & \\
5. Infeksi primer & $20(95,3)$ \\
& DD & $16(27,1)$ \\
& DBD & $6(14)$ \\
& SSD & \\
6. & Infeksi sekunder & $1(4,7)$ \\
& DD & $43(72,9)$ \\
& DBD & $37(86)$ \\
\hline
\end{tabular}


dibandingkan dengan perempuan $57(45,4 \%)$. Sebagian besar kasus mempunyai status gizi baik 82 $(66,6 \%)$. Berdasarkan diagnosis kasus DBD derajat 1 dan 2 lebih banyak dibandingkan DD dan SSD yaitu $59(47, \%)$ anak. Sebagian besar SSD adalah infeksi sekunder 37(86\%), sedangkan DD sebagian infeksi primer 20 (95,3\%). Gejala klinis tertera pada Gambar 1.

Dari Gambar 1 gambaran klinis yang mencolok adalah demam $115(93,5 \%)$, muntah $80(65,1 \%)$, nyeri perut $62(50,4 \%)$, ruam konvalesen $58(47,1 \%)$, mual $55(44,7 \%)$, pusing $24(19,5 \%)$, perdarahan gusi $8(6,5 \%)$, epitaksis $5(4,1 \%)$, melena $4(3,3 \%)$ dan
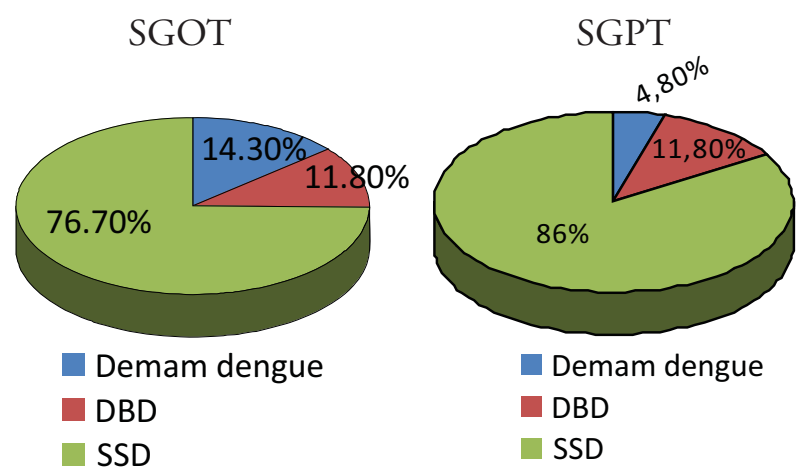

Gambar 2. Peningkatan kadar SGOT dan SGPT pada pasien demam berdarah dengue

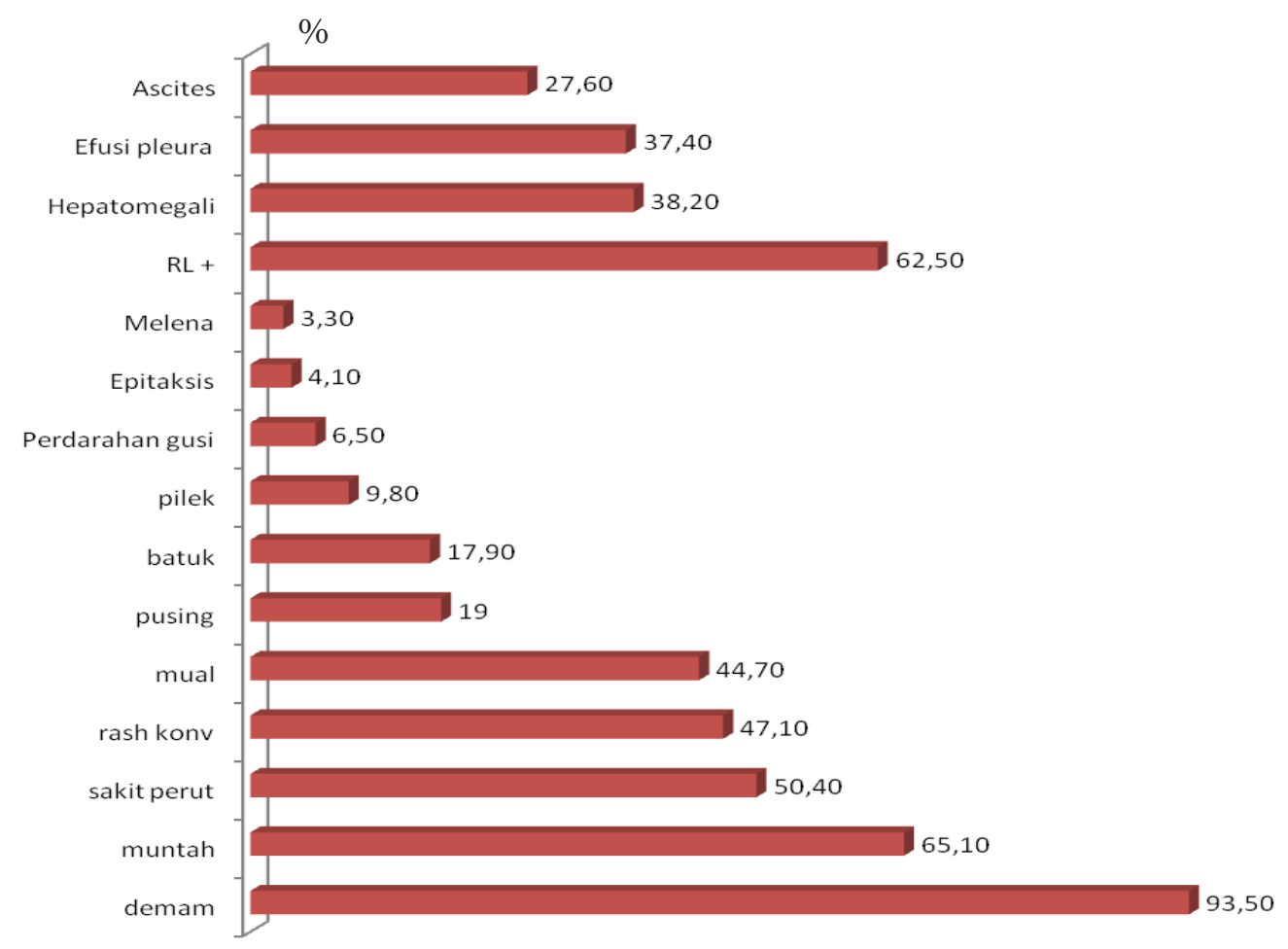

Gambar 1. Presentase gejala klinis demam berdarah dengue

gejala penyerta batuk 17 (17,9\%), pilek $12(9,8 \%)$. Pada pemeriksaan fisik ditemukan Rumple leed (RL) positif $77(62,6 \%)$, hepatomegali $47(38,2 \%)$, efusi pleura $46(37,4 \%)$ dan asites $34(27,6 \%)$. Kadar transaminase hati meningkat terutama pada SSD, SGOT $33(76,7 \%)$ dan SGPT 37(86,0\%), seperti tertera pada Gambar 2 .

Nilai rerata leukosit, hematokrit, dan trombosit tertera pada Gambar 4. Leukosit dan trombosit pada pasien SSD lebih rendah dibandingkan DBD dan DD dan perbedaan ini secara statistik bermakna.

\section{Terapi (Tabel 2)}

Penggunaan terapi cairan kristaloid merupakan terapi utama, pada DD 17 (81,1\%), DBD 51 (86,4\%) dan SSD 37 (86,1\%), sedangkan koloid paling banyak dipakai pada SSD 24 (56,1\%). Cairan koloid yang digunakan HES 6\%, komponen darah terbanyak digunakan pada SSD yaitu fress frozen flasma (FFP) 7 $(16,3 \%)$, PRC 4 (9,3\%) dan komponen trombosit 7 $(16,3 \%)$. Penggunaan antibiotik pada DBD $5(8,5 \%)$, SSD $17(39,5 \%)$. 
Tabel 2. Terapi pada pasien DD, DBD, dan SSD.

\begin{tabular}{lccc}
\hline Variabel & $\begin{array}{c}\text { DD } \\
\mathrm{n}=21\end{array}$ & $\begin{array}{c}\text { DBD } \\
\mathrm{n}=59\end{array}$ & $\begin{array}{c}\text { SSD } \\
\mathrm{n}=43\end{array}$ \\
\hline $\begin{array}{l}\text { Cairan (\%) } \\
\text { - Kristaloid }\end{array}$ & 81,1 & 86,4 & 86,1 \\
- Plas ma ekspander & - & 8,4 & 56,1 \\
- Komponen darah & & & \\
- FFP & - & 3,3 & 6,9 \\
- PRC & 4,8 & 1,6 & 9,3 \\
- Trombosit & - & 5,1 & 16,3 \\
Obat inotropik (\%) & - & - & 11,5 \\
Ventilator mekanik (\%) & - & - & 4,6 \\
Rerata perawatan (hari) & $(4 \pm 0,93)$ & $(5 \pm 0,23)$ & $(6 \pm 0,21)$ \\
Antibiotik (\%) & - & 8,5 & 39,5 \\
Rerata syok teratasi (menit) & - & - & $(47 \pm 0,89)$ \\
Angka kematian (\%) & - & - & 6,9 \\
\hline
\end{tabular}

pada kelompok umur 5-9 tahun yaitu 46,1\%. ${ }^{4}$ Tabel 1 memperlihatkan kasus terbanyak adalah DBD 59 (47,9\%), diikuti oleh SSD 43 (34,9\%), dan DD $21(17,2 \%)$. Data menunjukkan bahwa kasus yang datang atau dirujuk pada umumnya kasus DBD berat. Chairulfatah $\mathrm{dkk}^{7}$ melaporkan bahwa dari 128 kasus infeksi virus dengue, 19\% kasus disertai dengan syok, sedangkan Kabra dkk ${ }^{1}$ melaporkan dari 193 pasien klinis infeksi virus dengue 59\% disertai dengan syok. Di Amerika Latin Gonzales $\mathrm{dkk}^{8}$ medapatkan 29\% kasus DBD mengalami syok. Pasien DBD dan SSD pada umumnya adalah infeksi sekunder, sedangkan DD umumnya infeksi primer berdasarkan hasil serologi dengue rapid test (Panbio-Australia), tes ini mempunyai sensitivitas $98 \%$ dan spesifisitas $87 \% .{ }^{9}, 10$ Gejala klinis yang mencolok adalah demam $115(93,5 \%)$, muntah $80(65,1 \%)$, nyeri perut $62(50,4 \%)$, pusing 24
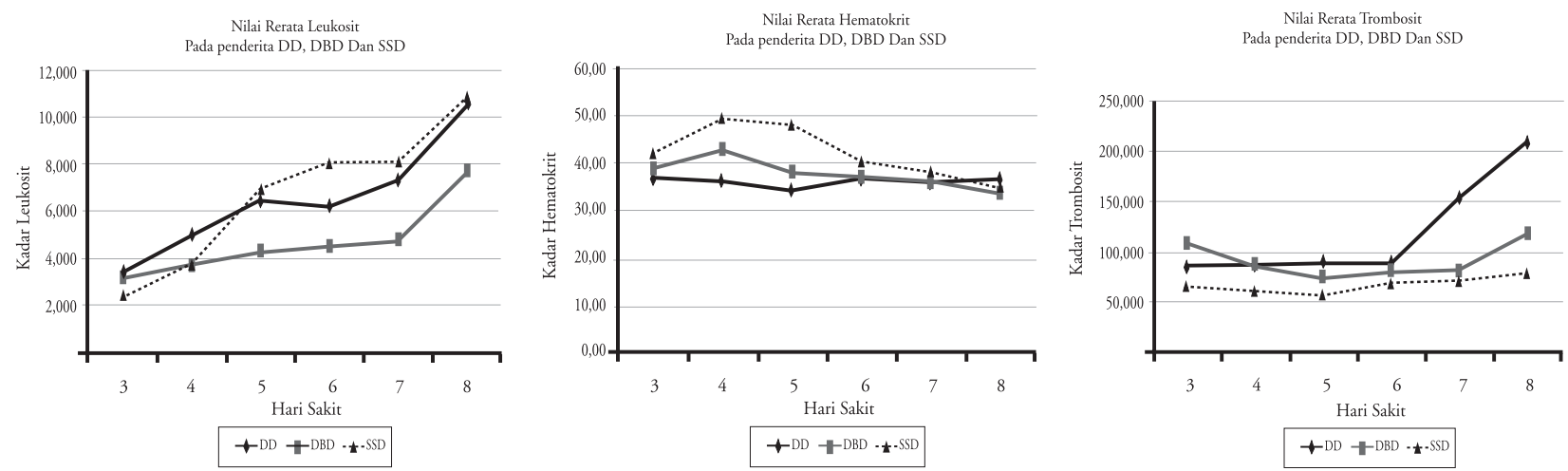

Gambar 3. Nilai rerata leukosit, hematokrit, dan trombosit pada pasien DD, DBD dan SSD

\section{Pembahasan}

Berdasarkan distribusi jenis kelamin dari 123 kasus, laki-laki 66 (54,6\%) lebih banyak dibandingkan dengan perempuan 57 (45,4\%), atau perbandingan laki-laki dan perempuan $1,1: 1$. Temuan ini tidak berbeda jauh dari penelitian yang dilakukan di Bagian IKA RSCM yang mendapatkan laki-laki perempuan 1,3:1 dan penelitian Suharyono ${ }^{4,5}$ mendapatkan perbandingan laki-laki dan perempuan 1,4:1. Kemungkinan berkaitan dengan kebiasaan nyamuk Aedes aegypti yang aktif menggigit pada siang hari dengan dua puncak aktivitas yaitu pada pukul 08.00-12.00 dan 15.00-17.00, pada jam tersebut anak bermain di luar rumah. ${ }^{6}$ Insiden tertinggi terdapat pada kelompok umur 5-10 tahun yaitu $52(42,4 \%)$, seperti hasil penelitian di Bagian IKA RSCM, yang melaporkan insiden tertinggi terdapat
(19,5\%), batuk $22(17,9 \%)$, dan pilek $12(9,8 \%)$. Pada penelitian Kautner dkk, ${ }^{11}$ demam, muntah, dan nyeri perut merupakan gejala yang mencolok. Pada pemeriksaan fisik, di dapatkan uji forniket positif pada $77(62,6 \%)$, hepatomegali $47(38,2 \%)$, dan efusi pleura $46(37,4 \%)$. Pada penelitian uji forniket di Thailand terhadap 108 pasien infeksi virus dengue mempunyai sensitivitas $90 \%$ dan spesifisitas $48 \%$, di Vietnam terhadap 598 kasus infeksi virus dengue mempunyai sensitivitas $42 \%$ dan spesifisitas $94 \%$. $^{1,12}$ Di Bangkok dan Kamphaeng Phet Thailand dilakukan penelitian terhadap 318 anak umur 6 bulan- 15 tahun infeksi virus dengue dan 72 anak terinfeksi virus lain dengan hasil uji forniket positif pada 88\% demam dengue, 91\% DBD derajat I, 95\% DBD derajat II, $91 \%$ pada SSD, dan $52 \%$ pada infeksi selain virus dengue. ${ }^{1}$ Hepatomegali $38,2 \%$, sama dengan penelitian 
Daniel $\mathrm{dkk}^{13}$ bahwa pada 38\% infeksi virus dengue terdapat hepatomegali. Pada pasien SSD terjadi peningkatan kadar SGOT pada $33(76,3 \%)$ dan SGPT 37 (80,0\%), ini sesuai dengan hasil penelitian Agus $\mathrm{dkk}^{14}$ pada SSD peningkatan nilai transaminase hati lebih tinggi di bandingkan pada DD dan DBD. Pada penelitian Mohan $\mathrm{dkk}^{15}$ peningkatan kadar SGOT/ SGPT terjadi karena gangguan fungsi hati yang bersifat sementara, terutama pada DBD dan SSD. Peningkatan transaminase hati terjadi akibat kerusakaan sel hati oleh invasi virus secara langsung atau merupakan respon imun sel pejamu. ${ }^{16,17,18}$ Nilai rerata angka leukosit pada hari ketiga dan keempat pada pasien SSD lebih rendah jika dibandingkan dengan DD maupun DBD dan ini bermakna secara statistik $(p=0,007)$. Penelitian Tanner $\mathrm{dkk}^{19}$ pada 364 subjek didapatkan $78 \%$ pasien infeksi virus dengue mengalami leukopenia $(<5.000 /$ ul), demikian juga nilai rerata hematokrit pasien DSS lebih tinggi dibandingkan dengan pasien DD dan DBD pada hari keempat dan kelima dan secara statistik bermakna $(p=0,049)$. Nilai hematokrit tertinggi terjadi hari keempat dan kelima, kemudian akan menurun. Penelitian Gonzales $\mathrm{dkk}^{8}$ pada pasien DBD didapatkan trombositopenia 100\%, hemokonsentrasi $93,4 \%$, leukopenia $71,3 \%$, dan kenaikan transaminase hati $82,8 \%$. Nilai rerata angka trombosit pasien SSD jauh lebih rendah dibandingkan dengan DD dan DBD (Gambar 3). Nilai trombosit $<50.000 /$ ul berhubungan dengan faktor prognostik. ${ }^{13}$ Pada penelitian Ayub dkk $^{19}$ trombositopenia terdapat pada 79,49\% kasus DD. Penggunaan cairan kristaloid merupakan terapi utama, baik pada DD, DBD maupun SSD. Pada SSD, cairan kristaloid digunakan pada 86,1\% kasus, sedang plasma ekpander 56,1\%. Cairan koloid digunakan pada resusitasi kedua pada SSD apabila dengan cairan kristaloid tidak membaik. Penelitian Bridget $\mathrm{dkk}^{20}$ menunjukkan tidak ada perbedaan bermakna pada resusitasi awal antar cairan kristaloid (RL) dengan koloid (dextran 70 atau HES 6\%), koloid lebih sering menyebabkan efek samping. Pada penelitian di Thailand, 30\%-50\% SSD mendapatkan cairan koloid. ${ }^{21}$ Penggunaan komponen darah (plasma, PRC dan trombosit) lebih sering pada SSD, 16,3\% pasien mendapatkan tranfusi trombosit oleh karena terjadi perdarahan aktif disertai trombositopenia, 9,3\% mendapatkan tranfusi PRC, sedangkan pada DBD $5,1 \%$ mendapatkan tranfusi trombosit dan 4,8\% transfusi PRC. Penelitian di Thailand mendapatkan penggunaan komponen darah 5\%-30\% pada kasus
DBD. ${ }^{21}$ Antibiotik masih digunakan pada SSD dengan komplikasi sepsis, 39,5\% SSD mendapatkan antibiotik oleh karena disertai sepsis. Angka kematian pasien SSD 6,9\%, pada umumnya kematian disebabkan oleh disseminated intravascular coagulation (DIC) atau multiple organ difunction syndrome (MODS) akibat syok lama. Pada penelitian di India, angka kematian pasien SSD 9,3\%, sedangkan di Philipina 2\%. ${ }^{1}$ Pada umumnya angka kematian oleh karena syok tidak teratasi lebih dari satu jam, sehingga terjadi komplikasi lainnya.

\section{Kesimpulan}

Demam berdarah dengue merupakan masalah kesehatan masyarakat, oleh karena morbiditas dan mortalitas masih tinggi. Gejala klinis yang mencolok demam, muntah, mual, nyeri perut, epitaksis, dan melena. Pada pemeriksaan fisik ditemukan uji forniket positif, ruam konvalesen, hepatomegali, efusi pleura, asites. Sindrom syok dengue sebagian besar infeksi sekunder, sedangkan demam dengue infeksi primer. Gambaran laboratorium yang mencolok kenaikan transaminase hati, leukopenia, trombositopenia, dan hematokrit. Rerata angka leukosit dan trombosit lebih rendah pada SSD dibandingkan dengan DD atau DBD, sedangkan rerata hematokrit lebih tinggi pada SSD. Penggunaan cairan kristaloid merupakan terapi utama baik pada SSD maupun DBD. Survival rate pada DD dan DBD di Bagian Anak RSUD Ulin Banjarmasin 100\% sedangkan SSD 96\%.

\section{Daftar Pustaka}

1. World Health Organization. Dengue, dengue haemorrhagic fever and Dengue shock syndrome in the context of the integrated management of childhood illness. Geneva 2005.

2. Sri Rezeki S. Hadinegoro. Seminar sehari pengelolaan infeksi virus dengue. Jakarta, 1997.

3. Halstead SB. Global epidemiology of dengue: health systems in disarray. Trop Med 1993;35:137-46.

4. Sumarmo. Penatalaksanaan demam berdarah dengue. Medika 1989;2:161-70.

5. Suharyono. Masalah penyakit demam berdarah dengue pada Pelita VI. Cermin Dunia Kedok 1994; 92:11-3.

6. Saleha $S$, Ismid. Bionomik Aedes aegypti, vektor utama demam berdarah dengue. Medika 1994;7:64-8. 
7. Chairulfatah A, Setiabudi D, Ridad A. Clinical manifestation of dengue haemorrhagic fever in children in Bandung Indonesia. Ann Soc Belg Med Trop 1995; 30:293-303.

8. Gonzales D, Osvaldo E, Peres J, Eric Martines, Suzan V, Castro G dkk. Classical dengue haemorrhagic fever resulting from two dengue infections spaced 20 years of more apart: Havana, dengue 3 epidemic 2001-2002. Int J Infect Dis 2005;9:280-5.

9. Aryanti. Manfaat tes dengue stick IgM dan IgG pada demam berdarah dengue. Dalam Makalah lengkap seminar: Penatalaksanaan demam berdarah dengue. Trop Dis Centre Unair, Surabaya 2001:62-8.

10. Cuzzobo AJ, Rowland D, Michel JL, Devine PL. Comparison of the Panbio dengue IgM dan IgG immunochromatographic card test and the Panbio dengue IgG immunochromatographic strip test. Panbio Pty Ltd 2000;41-8.

11. Kutner I, Robinson MJ, Kubnle U. Dengue virus infection: epidemiologi, pathogenesis, clinical presentation, diagnosis and prevention. J Pediatr 1997;131:516-24.

12. Phoung CX, Nhan NT, Wills B, Kneen R, Han NT, Mai TT dkk. Evaluation of the World Health Organization standart torniquet test in the diagnosis of dengue infection in Vietnam. Trop Med and Int Health 2002; 7:125-32.

13. Daniel H, Lybrati, Khin SA, Myint, Clinton K, Robert $\mathrm{V}$ dkk. A comparative study of leptospirosis and dengue in Thai children. Plos Negl Trop Dis 2007;1:111-7.

14. Agus D, Sekarwana N, Setiabudi S. Hubungan kadar aspartat aminotransferase (AST) dan alanin aminotransferase
(ALT) serum dengan spektrum klinis infeksi virus dengue pada anak. Sari Ped 2008; 9:359-62.

15. Mohan B, Parwati AK, Anand VK. Hepatic dysfunction in chilhood dengue infection. J Trop Med 2000;46:40-3.

16. Gubler DJ. Dengue and dengue haemorrhagic fever. Clin Microbiol Rev 1998;11:480-96.

17. Petdachai W. Hepatic dysfunction in children with dengue shock syndrome. Dengue Bull 2005;29:1-8.

18. Kalayanarooj S, Osotkrapan S, Nimmannitya S. Abnormal elevation of hepatic transaminase in dengue haemorrhagic fever patients. Studies/collaborative on dengue infection/dengue haemorrhagic fever at Queen Sirikit National Institute of Child Health (Children,s Hospital). Bangkok: WHO Collaborating Centre for Case Management;1991.

19. Ayub M, Khazarnidal M, Lubbad EH, Shahid S, Alyafi AY, Al-Ukayli S. Characteristic of dengue fever in large public hospital, Jeddah, Saudi Arabia. J Ayub Med Coll Abbottabd 2006;18:9-12.

20. Bridget AW, Nguyen M , Ha Loan, Dong TH, Tran TN, Thuy MD. Comparison of three fluid solution for resusitation in Dengue shock syndrome. N Engl J Med 2005;353:877-89.

21. Kalayanarooj S, Chaimongkol Y, Nimmannitya S. Volume of intravenous fluid, blood and blood components used in Dengue haemorrhagic fever patients. Study collaborative on dengue infections an Queen Sirikit National Institute of Child Health Hospital Bangkok. WHO collaborative centre for case management 1991:199-202. 